\title{
Erenumab in Mechanism-based Migraine Treatment
}

\author{
Mekanizma Temelli Migren Tedavisinde Erenumab
}

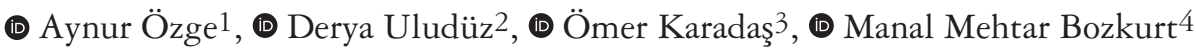 \\ ${ }^{1}$ Mersin University Faculty of Medicine, Department of Neurology, Mersin, Turkey \\ 2Istanbul University-Cerrahpasa, Cerahpasa Faculty of Medicine, Department of Neurology, Istanbul, Turkey \\ 3University of Health Sciences Turkey, Gulhane Training and Research Hospital, Clinic of Neurology, Ankara, Turkey \\ ${ }^{4}$ Novartis Pharmaceuticals, Istanbul, Turkey
}

\begin{abstract}
Migraine is a type of primary headache with recurrent attacks, negatively affects the daily living activities of sufferers because of its severity, and causes a heavy economic burden. The economic, social, and physical burdens of migraine grow with the increasing frequency of headache attacks. Mechanism-based treatments are increasingly needed, especially for those with chronic migraine (CM) or episodic migraine (EM) with frequent attacks. Conventional migraine-preventive medications have been essentially developed for some other diseases and shown to be also effective against migraine headaches. Efficacy, safety, and tolerability issues limit their use for an adequate duration, and most patients are under the risk of medication-overuse headache because of the ineffectiveness of attack treatments. In recent decades, a better understanding of migraine pathophysiology has given a new direction to migraine drug research to fulfill the unmet need for the development of migraine-specific medications. Calcitonin gene-related peptide (CGRP) has attracted attention with its potential role in migraine pathogenesis and has become the focus of drug research in this area as of the 1990s. The first monoclonal antibody developed and approved for the treatment of migraine is erenumab. Being the only therapeutic antibody against the CGRP receptor, erenumab differs from the other monoclonal antibodies for migraine prevention that target the CGRP ligand. Erenumab is a fully human, immunoglobulin G2 class monoclonal antibody with no immunomodulatory effect. It blocks the CGRP receptor with high affinity and selectivity and prevents binding of the CGRP ligand to this receptor. It does not have a significant effect on other receptors in the calcitonin receptor family. Erenumab has been shown to diminish the number of migraine days and the need for attack treatment and to improve patient-reported outcomes in patients with EM and CM.
\end{abstract}

Keywords: Erenumab, calcitonin gene receptor protein, migraine, preventive treatment, medication overuse

\section{Öz}

Migren ataklarla seyreden, şiddetli olması nedeniyle kişinin günlük yaşam aktivitelerini olumsuz etkileyen ve önemli ekonomik yüke neden olan primer baş ağrısıdır. Migrenin ekonomik, sosyal ve fiziksel yükü ağrı sıklığındaki artış ile birlikte artmaktadır. Özellikle kronik migrenli (KM) veya sık atak geçiren epizodik migrenli (EM) hastalarda mekanizma temelli tedavilere ihtiyaç her geçen gün daha fazla hissedilmektedir. Konvansiyonel önleyici tedaviler esasen farklı hastalıklara yönelik olarak geliştirilmiş, migren baş ağrısında da etkili oldukları çalışmalarda gösterilmiş tedavilerdir. Bu tedavilerin etkililiği ve istenmeyen etkileri ile ilgili sorunlar migrenli hastalarda yeterli süreyle kullanımlarını kısıtlamaktadır; çoğu hasta etkisiz atak tedavileri nedeniyle ilaç aşırı kullanım baş ağrısı riski altındadır. Yakın dönemde migren patofizyolojisinin daha iyi anlaşılması migrene özgü tedavilerin geliştirilmesine yönelik araştırmalara yeni bir yön vermiştir. Kalsitonin gen ilişkili peptid (CGRP), migren patogenezindeki rolüne ilişkin ipuçlarıyla dikkatleri üzerine çekmiş ve 1990’lı yıllardan başlayarak ilaç araştırmalarının odağı haline gelmiştir.

Migren tedavisine yönelik ilk geliştirilen ve kullanıma giren monoklonal antikor erenumabdır. CGRP reseptörüne karşı geliştirilmiş tek terapötik antikor olması ile migren profilaksisinde kullanılan ve CGRP ligandını hedef alan diğer monoklonal antikorlardan ayrışır. Erenumab insan yapısıyla tamamen aynı "(human)" olacak şekilde tasarlanmıştır; immünoglobulin G2 sınıfında yer alan, immünomodülatör etkisi olmayan bir monoklonal antikordur. Yüksek afinite ve seçicilikle CGRP reseptörünü bloke edip CGRP ligandının bu reseptöre bağlanmasını engeller. Kalsitonin ailesindeki diğer reseptörler üzerinde önemli bir etkisi bulunmamaktadır. EM ve KM'li hastalarda ağrılı gün sayısını ve atak tedavisine olan ihtiyacı azaltmada etkili bulunmuş, hasta geri bildirim sonuçlarını iyileştirmiştir.

Anahtar Kelimeler: Erenumab, kalsitonin gen ilişkili peptid, migren, önleyici tedavi, ilaç aşırı kullanım

Address for Correspondence/Yazışma Adresi: Aynur Özge Prof. MD, Mersin University Faculty of Medicine, Department of Neurology, Mersin, Turkey Phone: +90 32424100 01-31902 E-mail: aynurozge@gmail.com ORCID: orcid.org/0000-0003-2797-2398

Received/Geliş Tarihi: 15.04 .2021 Accepted/Kabul Tarihi: 11.07 .2021

${ }^{\circ}$ Copyright 2021 by Turkish Neurological Society

Turkish Journal of Neurology published by Galenos Publishing House. 


\section{Introduction}

Migraine accompanied by nausea, vomiting, and sensitivity to light and sound is a common type of headache that usually occurs as unilateral, throbbing, moderate-severe, and longlasting and recurrent attacks (1). Attacks vary in frequency and duration, negatively affecting the daily life and work productivity of sufferers $(2,3,4,5)$. The International Classification of Headache Disorders-3 diagnostic criteria defined migraine headache as episodic (<15 days/month) and chronic migraine (CM), having at least 15 headache days/month, with at least 8 days of having headaches with migraine features, for more than 3 months (1). Episodic migraine (EM) attacks can become more frequent over time for various reasons and progress into $\mathrm{CM}(6,7,8)$.

According to the Global Burden of Disease data, migraine affects more than 1.12 billion people worldwide, and its ageadjusted prevalence is $14.72 \%$ (9). It is more common in women than in men, and its prevalence peaks in the fourth decade (3034 years) (9). In a field study conducted in Turkey in 2008, the prevalence of migraine was $16.4 \%$ and that of $\mathrm{CM}$ was $1.7 \%$ when medication overuse was also included (10). The prevalence of migraine in Turkey increased slightly in 2013, reaching $16.7 \%$ (11). Migraine is the main cause of disability in individuals aged $<50$ years (12). It negatively affects people physically, socially, and functionally and reduces their quality of life $(2,4,5)$. The economic, social, and physical burdens of migraine grow with the increasing frequency of pain $(4,5,13)$. The burden of $\mathrm{CM}$ on the individual and society is greater because of health-related resource use and the frequency of accompanying comorbidities $(5,13,14)$. Many factors were found to determine the chronification and treatment resistance in patients with migraine. Medication overuse and cutaneous allodynia are independent risk factors for chronification (8). A study reported that the progression to the chronic form occurs at an average annual rate of $2.5 \%$ (6). The rate of progression from CM to EM was related to treatment success, which was $26 \%$ in 2 years, and it was observed more frequently in patients with a relatively low number of days with pain and those without allodynia (15). Effective treatment in migraine is important to prevent chronification as well as reduce the frequency and severity of pain and restore functionality $(13,16,17)$. The recommendation was to give preventive treatment to patients in cases of headache for $\geq 4$ days/month, attacks adversely affected daily life despite acute treatment, ineffective and/or contraindicated acute drugs, or known medication overuse (18). Conventional preventive treatments consist of medications that have been developed for various diseases and have demonstrated effectiveness in migraine headaches. The most commonly used drug groups for this purpose are beta blockers (propranolol, atenolol, and timolol), anticonvulsants (valproic acid and topiramate), antidepressants (venlafaxine, duloxetine, and amitriptyline), and calcium channel blockers (flunarizine). In the treatment of migraine, generally, these drugs should be started at a low dose, increased to the effective dose by dose titration, and used for a sufficient period. Adequate time is considered at least 2 months for the initial evaluation in terms of response to treatment (whether the drug works or not) and at least 6 months for the therapeutic effect (19). Low tolerability and suboptimal effectiveness are the main obstacles to the long-term use of conventional preventive therapies (20). In the Second International Burden of Migraine
Study, $28.3 \%$ and $44.8 \%$ of patients with EM and CM were using preventive treatment, respectively (20). In a database analysis, in which the data of patients with CM who were started on preventive treatment were evaluated retrospectively, the discontinuation rate was $75 \%$ at 6 months and $86 \%$ at 12 months (21). A study that retrospectively examined treatment patterns and health care use in a large patient population with health insurance found that the treatment was discontinued in 5.4 months (median) in patients with migraine for whom preventive treatment was initiated for the first time, and this period was 3.0 and 2.7 for the second and third preventive treatments, respectively (22). The limited effectiveness of these drugs, which should be taken one to several times a day regularly, and their side effects and tolerability problems restricts the treatment options and thus adversely affect the compliance of the patients with the treatment.

Although the limitations of the treatments used in migraine prophylaxis reveal the need for the development of new treatment options, no significant progress has been made in this regard until recently. In the last few decades, a better understanding of migraine pathophysiology has given a new direction to the search for migraine-specific treatments. Calcitonin gene-related peptide (CGRP) has attracted attention in this respect and has become the focus of drug research since the 1990s (23). CGRP is a member of the CGRP family, along with calcitonin, adrenomedullin, and amylin. It was first suggested in 1985 that CGRP, which was defined in 1982 and proven to exist in the trigeminovascular (TGV) system in 1984, might have a role in migraine development (24). CGRP is widely found in the central and peripheral nervous systems, including the TGV system, which has an important role in the pathophysiology of migraine (24). It plays a role in different processes of migraine such as in the activation of the TGV system, nociceptive signaling, vasodilation, neurogenic inflammation, and peripheral and central sensitization. To show its effect, it mainly binds to the CGRP receptor, which is the only member of the calcitonin receptor family of which relationship with migraine has been demonstrated so far. This receptor has three parts, calcitonin-like receptor (CLR), receptor activity-modifying protein 1 (RAMP1), and receptor component protein (RCP) (23). The RAMP1 protein is decisive because the receptor is specific to CGRP. RCP enables the receptor to couple with the cAMP signaling pathway and makes it functional. The CGRP receptor activates the cyclic adenosine monophosphate (cAMP) signaling pathway and increases cAMP. It activates phosphokinase $\mathrm{K}$, which plays a role in the vasodilator and neural effects of CGRP (25).

Within the framework of strategies to suppress the effects of CGRP in treatment of migraine, the main focus was the development of small molecules (gepants) that are CGRP receptor antagonists (26). The first members of this class were developed over 15 years ago, but clinical development was discontinued because of liver toxicity. Two of the second-generation gepants (ubrogepant and rimegepant), in which a similar problem was not observed, were recently approved for use. The development process of new gepants is still ongoing (27).

Monoclonal antibodies targeting CGRP or its receptor are another group of drugs of which potential to act on CGRP has been investigated $(26,28)$. CGRP administered intravenously for experimental purposes can trigger a migraine attack even though it does not cross the blood-brain barrier (29). This suggests that monoclonal antibodies, which have a limited ability to cross the 
blood-brain barrier because of their large molecular size, may have a role in migraine treatment. Monoclonal antibodies targeting CGRP and CGRP receptor have a very low rate of crossing the blood-brain barrier ( $<0.1 \%$ and 1500 times less than gepants), but are effective in migraine, supporting the view that the site of action of these drugs is outside the blood-brain barrier (30). Although they require subcutaneous or intravenous administration, their long half-lives allow infrequent use, suggesting that monoclonal antibodies may be an appropriate treatment approach for migraine prophylaxis and will contribute to increasing treatment compliance of and retention on treatment (30). Moreover, antibodies do not cause hepatotoxicity since they break up into amino acids by proteolysis; the possibility of drug-drug interactions is low because hepatic, renal, and biliary processes do not affect their elimination; the risk of non-target toxicity is low because of their high selectivity, and their tolerability is good (31). In addition, the European Headache Federation guideline on monoclonal antibodies acting on the CGRP ligand or its receptor states that the rapid onset of action of these therapeutic antibodies (usually within 1 month of the first dose) is an advantage over conventional treatments. This guideline recommends the use of monoclonal antibodies for at least 3 months, as the therapeutic benefit may increase with continuing treatment, and clinical improvement may occur over time in some patients whose conditions have initially deteriorated or who were unresponsive to treatment (32).

As of writing this review, four monoclonal antibodies (i.e., erenumab, fremanezumab, galcanezumab, and eptinezumab), with erenumab being the first, have been approved for the preventive treatment of EM and CM in many countries (32,33). Since erenumab is the only monoclonal antibody developed against the CGRP receptor, it differs from other monoclonal antibodies (i.e., galcanezumab, fremanezumab, and eptinezumab) targeting the CGRP ligand $(28,34)$. It blocks the CGRP receptor, preventing CGRP from binding to this receptor. It was approved by the Food and Drug Administration in the USA in May 2018 and by the European Medicines Agency in the European Union in July of the same year, to be administered subcutaneously (35) at a dose of 70 $\mathrm{mg}$ or $140 \mathrm{mg}$ once a month (34). The recommendation was to administer fremanezumab as once-monthly subcutaneous injection (225 mg) or as three consecutive subcutaneous injections every 3 months (36). Regarding galcanezumab, the recommendation was to administer a loading dose of $240 \mathrm{mg}$ (two consecutive subcutaneous injections of $120 \mathrm{mg}$ ), followed by a monthly injection (120 mg) (37). Unlike other monoclonal antibodies indicated in migraine prophylaxis, eptinezumab is administered intravenously (100 mg or $300 \mathrm{mg}$ every 3 months) (38).

Erenumab was designed to have a low risk of immunogenicity (39). It is a monoclonal antibody in the structure of "human" immunoglobulin G2 (IgG2), which has the same amino acid sequence as in humans (34). Among the approved therapeutic antibodies for migraine prophylaxis, erenumab is the only monoclonal antibody with a "human" feature (28). The binding affinity of IgG2 to immune effector cells is very low $(40,41)$. Therefore, from a biotechnological point of view, $\operatorname{IgG} 2$ is a preferred IgG subclass in therapeutic antibody development (41). Since its target molecule, the CGRP receptor, is located outside the immune system, erenumab is not expected to have an immunomodulatory effect (26). Erenumab blocks the CGRP receptor with high affinity and selectivity, preventing the binding of the CGRP ligand to this receptor, and it has no significant effect on other members of the calcitonin receptor family (31).

\section{Clinical Development Program}

The clinical development program of erenumab for migraine mainly consisted of four studies conducted in EM or CM $(42,43,44,45)$. Another study included in this program was the LIBERTY (phase IIIB) study conducted in patients with EM who had not responded to 2-4 preventive treatments before (46). Basic information about these studies is summarized in Table 1 . In a dose-determination study, only $70 \mathrm{mg}$ of erenumab among doses of 7,21 , and $70 \mathrm{mg}$ administered once a month was superior to placebo in terms of efficacy (42). Therefore, the efficacy and safety of $70 \mathrm{mg}$ and/or $140 \mathrm{mg}$ erenumab were investigated in subsequent studies $(43,44,45,46)$. More than 2500 patients were treated with erenumab in registry studies (47). In development studies, patients were randomized to the erenumab $70 \mathrm{mg}$ or 140 $\mathrm{mg}$ arms at the start of the double-blind treatment period (DBTP) $(42,43,44,45,46)$. Patients who completed placebo-controlled DBTP in the clinical development program were included in the active treatment period (ATP) ranging from 28 to 256 weeks (dose blind in the STRIVE study, open label in others) (Table 1). In addition to the primary and secondary efficacy and safety analyses in the datasets of the studies, various post-hoc and subgroup analyses (such as the onset of the clinical, efficacy in patients with a history of treatment failure, and medication overuse) that could guide clinical practice were also performed.

\section{Effectiveness}

The effect of erenumab starts from the first use and continues up to 4 weeks (subsequent erenumab administration) in patients with EM and CM (48). The primary efficacy endpoint for the first four studies in Table 1 was the change from baseline in the number of monthly migraine days (MMD) in the last part of the placebo-controlled DBTP (last 4 weeks for the 12-week studies, last 3 months for the 24-week STRIVE study). A reduction of $\geq 50 \%$ from baseline in MMD (proportion of responding patients) and the change from baseline in the number of monthly acute migraine-specific medication days (AMSMD) were the main secondary endpoints $(42,43,44,45)$. The primary efficacy endpoint of the LIBERTY trial was the proportion of patients who achieved $\mathrm{a} \geq 50 \%$ reduction in MMD from baseline in the last 4 weeks of the double-blind period (46). As shown in Table 2, erenumab reduced MMD and AMSMD more than the placebo in all phase III/IIIB studies included in the clinical development program, and the proportion of patients with $\mathrm{a} \geq 50 \%$ reduction in MMD was higher in the erenumab treatment groups than in the placebo group $(43,44,45,46)$. The findings in the ATP show that the proven efficacy of $70 \mathrm{mg}$ and $140 \mathrm{mg}$ erenumab in DBTP is consistently maintained in the long term (up to 5 years for EM, 1 year for CM) $(49,50,51)$.

\section{Episodic migraine}

The main efficacy results of DBTP of studies other than the dosing study included in the clinical study program are summarized in Table 2. In the 24-week placebo-controlled DBTP of the STRIVE trial $(\mathrm{n}=995)$, erenumab $70 \mathrm{mg}$ and $140 \mathrm{mg}$ were efficacious in reducing MMD and AMSMD from baseline and increasing the proportion of patients with a $\geq 50 \%$ reduction 
Table 1. Main characteristics of phase II and phase III/IIIB studies in the erenumab clinical development program

\begin{tabular}{|c|c|c|c|c|c|}
\hline $\begin{array}{l}\text { Study (references) } \\
\text { Number of } \\
\text { randomized } \\
\text { patients }\end{array}$ & $\begin{array}{l}\text { Sun et al. } \\
\mathrm{N}=483\end{array}$ & $\begin{array}{l}\text { Tepper et al. }(43) \\
\mathrm{N}=667\end{array}$ & $\begin{array}{l}\text { Goadsby et al. } \\
(44) \text { (STRIVE) } \\
\mathrm{N}=955\end{array}$ & $\begin{array}{l}\text { Dodick ve ark. } \\
\text { (45) (ARISE) } \\
\mathrm{N}=577\end{array}$ & $\begin{array}{l}\text { Reuter ve ark. (46) } \\
\text { (LIBERTY) } \\
\mathrm{N}=246\end{array}$ \\
\hline Patient group & $\begin{array}{l}18-60 \text { years, EM } \\
\text { EM history } \geq 12 \\
\text { months } \\
\text { No preventive } \\
\text { therapy or failure } \\
\text { of } \leq 2 \text { preventive } \\
\text { treatments }\end{array}$ & $\begin{array}{l}18-65 \text { years, } \mathrm{CM} \\
\text { CM history } \geq 12 \\
\text { months } \\
\text { No preventive } \\
\text { therapy or failure } \\
\text { of } \leq 3 \text { preventive } \\
\text { treatments } \\
\text { including patients } \\
\text { with medication } \\
\text { overuse }\end{array}$ & $\begin{array}{l}18-65 \text { years, EM } \\
\text { EM history } \geq 12 \\
\text { months } \\
\text { No preventive } \\
\text { therapy or failure } \\
\text { of } \leq 2 \text { preventive } \\
\text { treatments }\end{array}$ & $\begin{array}{l}18-65 \text { years, EM } \\
\text { EM history } \geq 12 \\
\text { months } \\
\text { No preventive } \\
\text { therapy or failure } \\
\text { of } \leq 2 \text { preventive } \\
\text { treatments }\end{array}$ & $\begin{array}{l}\text { 18- } 65 \text { years, EM } \\
\text { EM history } \geq 12 \\
\text { months } \\
\text { Failure of } 2-4 \\
\text { preventive treatments, } \\
\text { migraine symptoms } \\
4-14 \text { days/month and } \\
\text { headache }<15 \text { days/ } \\
\text { month* at screening } \\
\text { and baseline }\end{array}$ \\
\hline
\end{tabular}

in MMD (Table 2) (44). These effects persisted for 52 weeks, including the study's 28-week ATP ( $\mathrm{n}=845)$ (50). In patients treated with erenumab $70 \mathrm{mg}$ or $140 \mathrm{mg}$, at the end of 1 year, a decrease of $4.2 \pm 0.2$ and $4.6 \pm 0.2$ days, respectively, was found in ATP compared with the onset of DBTP (mean MMD 8.3), and a decrease of $1.1 \pm 0.2$ and $1.8 \pm 0.2$ days, respectively, was noted when compared with onset of the ATP. In patients who switched from placebo to erenumab at onset of the ATP, doses of 70 and 140 $\mathrm{mg}$ administered every 4 weeks resulted in a decrease of $2.2 \pm 0.4$ days and $2.9 \pm 0.4$ days, respectively, in MMD. A reduction of $\geq 50 \%$ from baseline in MMD was observed in $61.0 \%$ and $64.9 \%$ of patients in the erenumab $70 \mathrm{mg}$ group and erenumab 140 mg group, respectively, and a reduction of $\geq 75 \%$ from baseline in MMD was observed in $38.5 \%$ and $40.8 \%$ of patients in the erenumab $70 \mathrm{mg}$ group and erenumab $140 \mathrm{mg}$ group, respectively. The proportion of patients who achieved a $100 \%$ reduction from baseline in MMD was $19.8 \%$ and $21.2 \%$ in erenumab 70 and 140 $\mathrm{mg}$ groups, respectively (50). In a subgroup analysis of the STRIVE trial, erenumab was efficacious in patients with EM who had failed $\geq 1$ or $\geq 2$ prior preventive treatments (52). Both doses of erenumab administered in these subgroups significantly decreased MMD at the $4^{\text {th }}$ to $6^{\text {th }}$ months of DBTP compared with baseline. AMGS was 2.0 days $(1.2-2.8 ; \mathrm{p}<0.001)$ lower in patients with $\geq 1$ preventive treatment failure receiving $70 \mathrm{mg}$ erenumab and 2.5 days (1.7-3.4; $\mathrm{p}<0.001$ ) lower in patients with $\geq 1$ preventive treatment failure receiving $140 \mathrm{mg}$ erenumab compared with the placebo [difference $95 \%$ confidence interval, (CI)]. In patients with $\geq 2$ preventive therapy failures, AMGS was $1.3(0.0-2.6 ; \mathrm{p}<0.05)$ days lower in the erenumab $70 \mathrm{mg}$ group and $2.7(1.4-4.0 ; \mathrm{p}<0.001)$ days lower in the erenumab $140 \mathrm{mg}$ group. AMGS decreased $\geq 50 \%$ from baseline in $38.6 \%$ of patients with $\geq 1$ preventive treatment failure receiving $70 \mathrm{mg}$ erenumab and $39.7 \%$ of those with $\geq 1$ preventive treatment failure treated $140 \mathrm{mg}$ erenumab (these rates were $26.5 \%$ and $36.2 \%$, respectively, in patients with $\geq 2$ preventive treatment failure). AMSMD improvements were also observed in these subgroups (52). The long-term efficacy of erenumab in patients in whom previous preventive therapy had failed was also maintained. In the STRIVE study, $52.3 \%$ (erenumab $70 \mathrm{mg}$ ) and $55.0 \%$ (erenumab $140 \mathrm{mg}$ ) of patients with a history of at least one treatment failure achieved $\geq 50 \%$ MMD improvement from baseline at year 1 (weeks 49-52) compared with baseline (before DBTP), and both doses of erenumab produced a consistent reduction in AMSMD over 1 year (53). As shown in Table 2, in the LIBERTY study conducted in patients with EM who had failed 2-4 prior preventive treatments, erenumab $140 \mathrm{mg}$ decreased MMD and AMSMD in the last 4 weeks (weeks 9-12) of DBTP compared with baseline. With erenumab, a $\geq 50 \%$ reduction in MMD was achieved in $30 \%$ of the patients ( $p=0.002$ for difference versus placebo), and a reduction of $\geq 75 \%$ ( $\mathrm{p}=0.025$ for difference versus placebo) was found in $12 \%$ of the patients (46). All patients enrolled in the 3-year open-label treatment period (OLTP) of the LIBERTY trial were treated with erenumab $140 \mathrm{mg}$. Data for the first 112 weeks showed that MMD decreased $\geq 50 \%, \geq 75 \%$, and $100 \%$ from baseline in $57.2 \%, 30.6 \%$, and $16.2 \%$ of the patients, respectively (54). For patients who switched from placebo to erenumab at the onset of OLTP, the corresponding rates were $61.2 \%, 31.8 \%$, and $17.6 \%$, respectively (54). The $1.8 \pm 0.4$ day decrease in MMD from baseline in the last 4 weeks (weeks 9-12) of OLTP was also observed in the first- and second-year interim analyses of OLTP [52 weeks: 3.7 (4,1); 112 weeks: 4.2 (5.0)] and persisted $(46,54)$. The longest timeframe results of erenumab came from the 256-week OLTP following 12-week DBTP of a phase II study in patients with EM (49). 


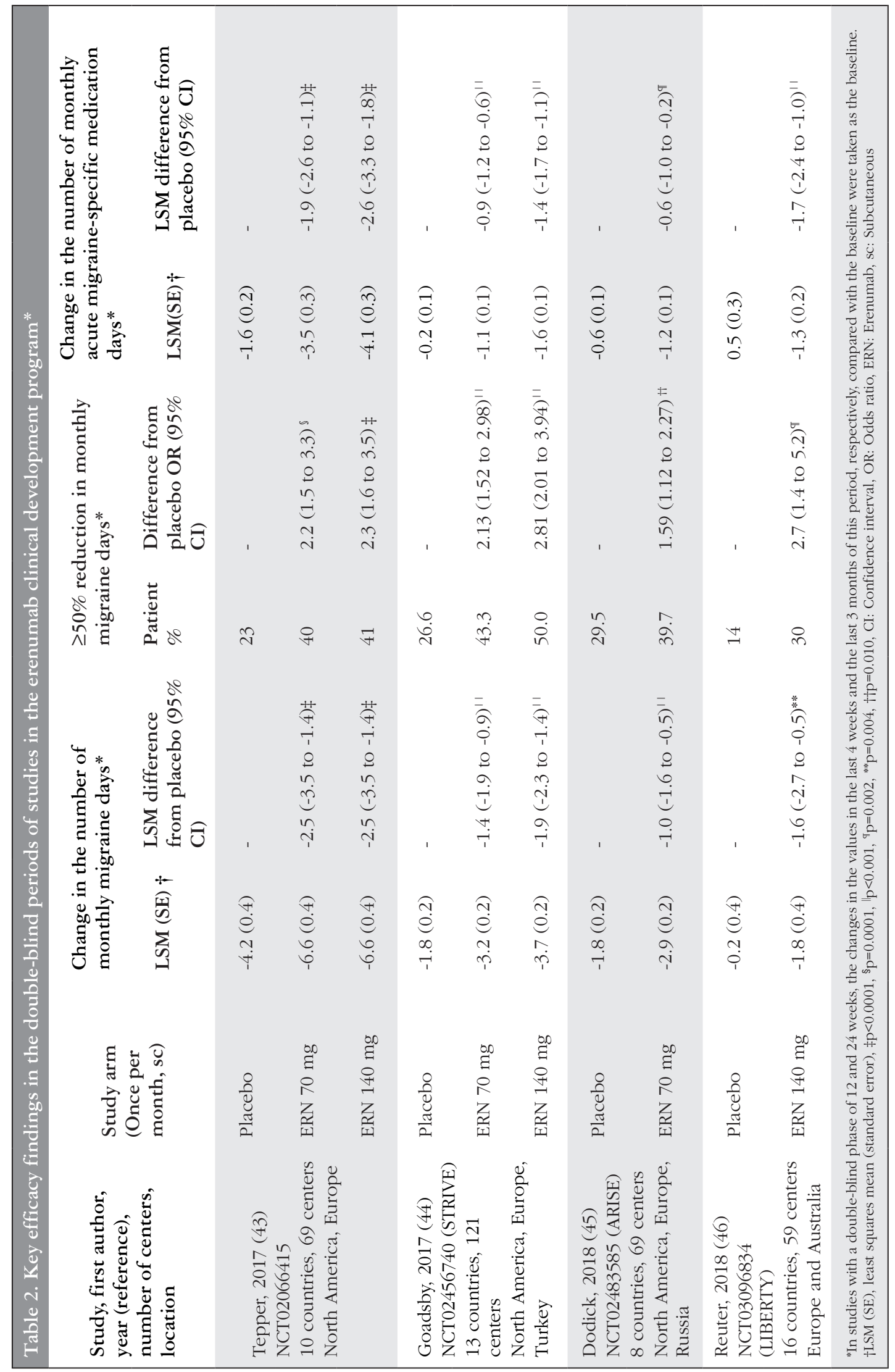


In the first 2 years of this period, patients were treated with 70 $\mathrm{mg}$ erenumab, and with the protocol change, the dose of patients who completed their second year was increased to $140 \mathrm{mg}$ to obtain long-term safety data regarding high-dose treatment (49). The mean MMD of $8.7 \pm 0.2$ days at the beginning of the study (before double-blind treatment) decreased by $5.3 \pm 0.3$ from baseline in the last 4 weeks of the 5 -year OLTP, and the reduction rates in MMD were $\geq 50 \%, \geq 75 \%$, and $100 \%$ in $71 \%, 47.1 \%$, and $35.5 \%$ of the patients, respectively. The mean AMSMD of $6.2 \pm 0.2$ at baseline decreased by $4.4 \pm 0.3$ days in the last 4 weeks of OLTP (49).

\section{Chronic Migraine}

In the clinical development program, the efficacy of erenumab in patients with CM was investigated in the pivotal study of 12week DBTP and in the 52-week OLTP, which included patients who completed the pivotal study $(43,51)$. As presented in Table 2 , both doses of erenumab (70 $\mathrm{mg}$ and $140 \mathrm{mg}$ ) in the main study reduced MMD and AMSMD; approximately $40 \%$ of patients had a $\geq 50 \%$ reduction from baseline in MMD (43). Patients participating in OLTP were initially started on $70 \mathrm{mg}$ erenumab. As the primary endpoint of the study was related to safety, the protocol was subsequently modified to obtain more data on highdose treatment $(140 \mathrm{mg} / \mathrm{month})$, and all patients who had not yet completed the first 28 weeks of the study or who were new to the study were treated with erenumab $140 \mathrm{mg}$. The reduction in MMD in DBTP compared with the baseline study continued in the OLTP as well. The mean MMD (95\% CI) at week 52 of OLTP was 8.5 (7.6-9.4) days and 10.5 (9.4-11.5) days lower than that of the baseline study in the erenumab $70 \mathrm{mg}$ and $140 \mathrm{mg}$ groups, respectively. The proportions of patients with $\geq 50 \%$ reduction in MMD at week 52 of OLTP were $67.3 \%$ and $53.3 \%$ for 140 $\mathrm{mg}$ and $70 \mathrm{mg}$ erenumab, respectively, which were higher than the rates in DBTP ( $41.0 \%$ and $40.0 \%$, respectively) (51). The mean AMSMD, which was 9.5 at the start of the main study, also decreased consistently to 4.9 and 4.5 days at weeks 40 and 52 of OLTP, respectively (51). In addition, in $54.1 \%$ (95\% CI 46.661.6) of patients treated with erenumab in the 12 -week main study, CM converted to EM, and in 96.8\% (95\% CI 91.1-99.3) of those with EM in the first 12 weeks of OLTP, EM persisted in the long-term follow-up (after 64 weeks). Of the patients without conversion from CM to EM in the main study, $43.4 \%$ (95\% CI 32.5-54.7) of cases progressed to EM within the first 12 weeks of OLTP, and in $77.8 \%$ of those patients, EM remained after 64 weeks (95\% CI 60.9-89.9) (55). The findings show that erenumab provides a consistent and sustainable long-term clinical improvement in patients with CM. A subgroup analysis of the 12 -week CM pivotal study evaluated the efficacy of erenumab in patients with and without a history of preventive treatment failure (56). Erenumab reduced MMD more than the placebo at the third month of the study (last month of DBTP) compared with baseline in those with a history of treatment failure. In patients with a history of $\geq 2$ preventive treatment failures, the reduction in MMD [least squares mean $(95 \% \mathrm{CI})$ ] was $4.3(2.8-5.8)$ days more in the $140 \mathrm{mg}$ erenumab group and $2.7(1.2-4.2)$ days more in the $70 \mathrm{mg}$ erenumab group compared with the placebo group $(\mathrm{p}<0.001$ for both). In patients with prior treatment failure, erenumab $140 \mathrm{mg}$ was more effective than erenumab $70 \mathrm{mg}$ in both reducing MMD and increasing the proportions of patients achieving $\geq 50 \%$ and $\geq 75 \%$ reductions in MMD from baseline. Erenumab also reduced AMSMD more in patients with a history of preventive treatment failure. The higher baseline AMSMD may have played a role in this outcome in patients who had previous treatment failure (56).

Erenumab reduced MMD and AMSMD in patients with CM with a history of medication overuse and clinical improvement was accompanied by an increase in the quality of life and a decrease in disability (57). In patients with previous preventive treatment failure and medication overuse ( $\geq 15$ days of simple analgesic or $\geq 10$ days of triptan, ergotamine, or combination therapy) during the 4-week baseline, erenumab reduced monthly acute headache medication use more than the placebo. The number of days of acute headache medication use per month [LSM (95\% CI)] was $2.6(1.2-4.0)$ days and $4.3(2.9-5.6)$ days lower in the $70 \mathrm{mg}$ and $140 \mathrm{mg}$ erenumab groups, respectively, than in placebo group ( $\mathrm{p}<0.001$ for both) (58). A study reported that $81 \%, 72 \%$, and $70 \%$ of patients who had overused simple analgesic, triptan, or combined analgesic therapy, respectively, at the baseline of the CM pivot study, stopped using these drugs at the end of the 52-week extension study (59).

When the efficacy of erenumab was evaluated in patients without allodynia [Allodynia Symptom Checklist (ASC)-12 total score $<3$ ] and in patients with moderate-to-severe allodynia (ASC$12 \geq 6$ ), MMD at 3 months was 5 (1.4-3.7) days lower in the erenumab $70 \mathrm{mg}$ group $(\mathrm{p}=0.001)$ and $3.3(1.3-5.3)$ days lower in the erenumab $140 \mathrm{mg}$ group $(\mathrm{p}<0.001)$ compared with the placebo. This suggested that allodynia did not negatively affect the efficacy of erenumab in patients with CM (60).

\section{Patient-reported Outcomes}

Effects of $70 \mathrm{mg}$ and $140 \mathrm{mg}$ doses of erenumab on the healthrelated quality of life, functioning, and migraine-related disability in patients with EM and CM were evaluated with the MigraineSpecific Quality of Life Questionnaire (MSQ), Headache Impact Test-6 (HIT-6), Migraine Disability Assessment Scale (MIDAS), and they are evaluated only in patients with CM with Patient Feedback Results Assessment Information System (PROMIS) Pain Interference Scale short form 6b. As summarized in Table 3, erenumab was effective in improving social and physical quality of life and reducing migraine-related disability in patients with EM and $\mathrm{CM}(61,62)$.

In a post-hoc analysis evaluating HIT-6, MIDAS and MSQ scores at 6 months in patients with EM who had failed $\geq 1$ previous preventive treatment, and HIT- 6 and MIDAS at 12 weeks in patients with $C M$ who had failed $\geq 1$ and $\geq 2$ previous preventive treatments, and in a subgroup analysis evaluating PROMIS data, erenumab $(70 \mathrm{mg}$ and $140 \mathrm{mg}$ ) provided clinically significant improvement in all scores compared with baseline of studies $(63,64)$.

\section{Safety Results}

Findings from the double-blind and OLTP of the placebocontrolled studies in phase II/III that included nearly 3.000 patients with EM and CM showed that erenumab was generally safe and well tolerated $(42,43,44,45,46,49,50,51,54)$. In two systematic reviews and meta-analysis based on randomized controlled trials in the clinical development program, no difference was found regarding the development of adverse events (AEs) and serious AEs (SAEs) between $70 \mathrm{mg}$ and $140 \mathrm{mg}$ doses of erenumab or between placebo and erenumab $(65,66)$. 


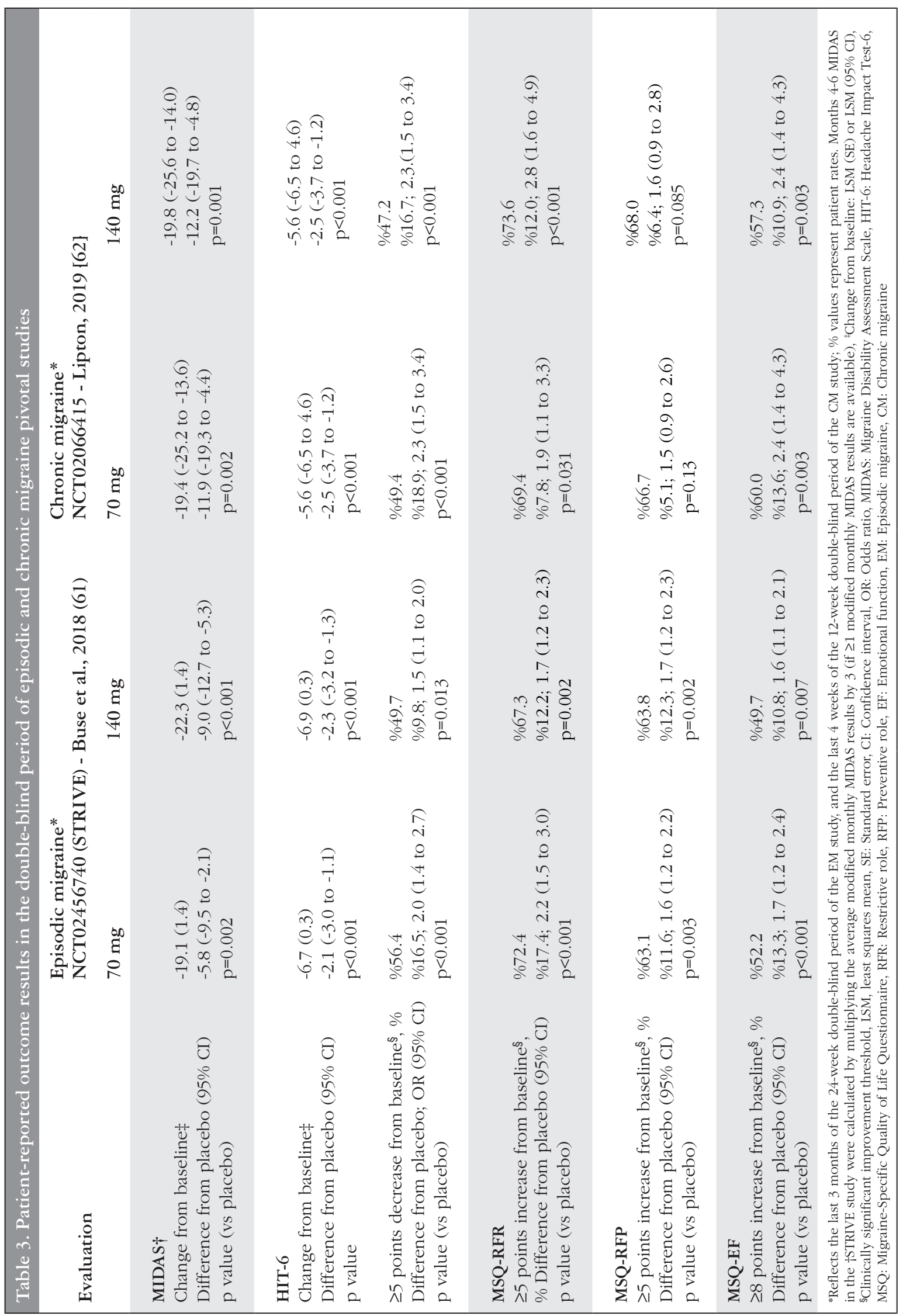


In the 24-week DBTP of the STRIVE study in patients with EM, the top 3 most commonly reported (percentage of patients) AEs were nasopharyngitis (9.9\%), upper respiratory tract infections ( URTIs) $(6.7 \%)$, and injection site pain $(3.2 \%)$ in the erenumab $70 \mathrm{mg}$ group, and nasopharyngitis (11.0\%), URTIs (4.7\%), sinusitis $(3.4 \%)$, and constipation $(3.4 \%)$ in the erenumab 140 $\mathrm{mg}$ group (44). Considering the duration of exposure to erenumab during the 28-week ATP, URTIs were the most common AEs with both erenumab doses (due to the change in the new version of the $\mathrm{AE}$ reporting terminology, nasopharyngitis was reported as URTI, unlike in DBTP) (50). Most AEs seen in patients receiving erenumab were mild to moderate. A patient in the erenumab 140 $\mathrm{mg}$ arm of the study with cardiac conduction defect (first-degree atrioventricular block and intraventricular conduction defect), mitral valve insufficiency, and a history of hyperlipidemia died of heart failure, and a genetic, arrhythmogenic structural anomaly associated with sudden cardiac death was found at autopsy (50). The proportion of patients who discontinued erenumab because of AE was $2.2 \%$ for both erenumab doses $(2.5 \%$ in the placebo arm) in the DBTP and $1.4 \%$ and $2 \%$ in the erenumab $70 \mathrm{mg}$ and 140 $\mathrm{mg}$ arms during the 28-week ATP, respectively $(44,50)$.

In the 12-week DBTP of the study in patients with CM, the top 3 most common AEs were injection site reactions (4\%), nasopharyngitis (3\%), and URTIs (3\%) in the erenumab $70 \mathrm{mg}$ group. In the erenumab $140 \mathrm{mg}$ group, the top 3 most common AEs were constipation (4\%), injection site reactions (4\%), and muscle spasms $(4 \%)$. Constipation was not observed in the erenumab $70 \mathrm{mg}$ group, and muscle spasms were observed in less than $1 \%$ of patients (43). In the 52-week OLTP that included patients who completed this study, most AEs in patients receiving erenumab were mild-to-moderate, and no life-threatening or fatal AE was observed. Considering the duration of exposure to erenumab, the most common AEs were viral uURTIs (16.4/100 patient-years), URTIs (7.2/100 patient-years), and sinusitis (7.1/100 patient-years) (51). Treatment was terminated because of $\mathrm{AE}$ in $<1 \%$ of patients ( 2 patients receiving erenumab $140 \mathrm{mg}$ ) in the 12 -week DBTP and in $2.6 \%$ of patients in the 1 -year OLTP (erenumab $70 \mathrm{mg}, 9$ patients; erenumab $140 \mathrm{mg}, 7$ patients) $(43,51)$. In a subgroup analysis of two pivotal studies conducted in CM and EM, the safety and tolerability of erenumab in the 12week period of DBTP in terms of cardiovascular, cerebrovascular, and peripheral vascular events were comparable in different age groups (18-40, >40-50, >50-55, and >55 years). was safe and well-tolerated in older patients. Sedation, cognitive dysfunction, and anticholinergic AEs were not observed in patients receiving erenumab (67).

In the analysis of pooled data from the four phase II/III studies in the clinical development program, the placebo, erenumab 70 $\mathrm{mg}$, and erenumab $140 \mathrm{mg}$ groups were comparable regarding the development of vascular events during the 12-week period of DBTP. During clinical development, no difference was found in the occurrence of vascular events between the double-blind and OLTP (68). Hypertension (mainly after the first injection and within 7 days) was reported in the post-marketing period. Thus, this situation should be taken into account in the follow-up (69). Based on the 12-week DBTP findings of studies in patients with EM and CM, hypertension or diastolic hypertension was reported in $0.9 \%, 0.8 \%$, and $0.2 \%$ of patients in the placebo, erenumab $70 \mathrm{mg}$, and erenumab $140 \mathrm{mg}$ groups, respectively. These findings and current long-term safety findings of the clinical trial program do not indicate an increased risk for hypertensive episodes $(49,50,51,54,69)$. The increase in blood pressure of 2-3 $\mathrm{mmHg}$ observed within the 5-year OLTP in patients with EM was compatible with the age-related change observed in the Framingham Heart Study $(49,70,71)$. The rate of hypertension in the study was lower than that observed in the placebo group (1.9 and 3.8/100 patient-years, respectively) in the pooled analysis of double-blind, placebo-controlled studies $(49,72)$.

The longest-term safety data on erenumab were based on the results of the 5-year OLTP of the phase II study conducted in patients with EM, which demonstrated that erenumab was well tolerated in the long term (49). No increase was noted in the incidence of AE or SAE over time, and no new cases of safety emerged. Considering the duration of exposure to erenumab, the most common AEs were nasopharyngitis (10.6/100 patient-years), URTI (6.7/100 patient-years), and influenza (4.6/100 patientyears) (49). The constipation rate (1.8/100 patient-years) was lower than the pooled data (7.0/100 patient-years) (72) for the 12 week period of DBTPs of the four placebo-controlled studies in the clinical development program, and no patients discontinued treatment (49). Eighteen, (4.7\%; 1.3/100 patient-years) patients discontinued erenumab treatment because of AEs in the 5-year OLTP (49).

Furthermore, $6.3 \%$ (56/884) of patients receiving erenumab $70 \mathrm{mg}$ in the DBTP of four placebo-controlled studies developed erenumab-binding antibodies, and antibodies became negative in 2 of 3 patients with neutralizing antibody ( $\mathrm{Nab}$ ) positivity. Binding antibody developed in 2.6\% (13/504) of patients receiving erenumab $140 \mathrm{mg}$, and $\mathrm{Nab}$ was not detected. More than half of the patients with binding antibody positivity who continued treatment were antibody negative at the end of the study. Antibody development did not adversely affect the efficacy and safety of erenumab (73). The safety results of erenumab for the 5-year longterm OLTP showed that the probability of developing antibodies to erenumab was low, and antibodies developed especially in the first 6 months of treatment and tended to disappear over time. Moreover, 30 (76.9\%) of 39 patients who developed binding antibodies and $2(66.7 \%)$ of 3 patients who developed Nab in the 5 -year OLTP became negative for antibodies over this period (49).

\section{Real-life Studies}

In a real-life study conducted in Italy, erenumab was given to patients with frequent EM (9-14 days/month; mean number of previous failed treatments, 3.7) or CM (mean number of previous failed treatments, 5.2) with a history of treatment failure. Erenumab $70 \mathrm{mg}$ was initiated, and the dose was increased to 140 $\mathrm{mg}$ in week 8 in patients who did not respond adequately. MMD (CM, 12.9 days reduction), pain intensity assessed by visual analog scale (EM, 1.8; CM, 2.6 units reduction) and HIT-6 score (EM, 10.5; CM, 12.9 reduction) significantly improved from baseline. In $2 / 3$ of patients with frequent EM and CM, MMD was reduced by $\geq 50 \%$. Of patients whose erenumab dose was increased to 140 $\mathrm{mg}, 69.8 \%$ benefited from the dose increase. Erenumab was well tolerated by patients, and mild-to-moderate AEs observed in $13.1 \%$ of the patients, with constipation as the most common AE $(9.1 \%)(74)$.

In a real-life study of adults with CM aged 18-65 years in whom at least four different classes of oral preventive therapy or 
onabotulinum toxin A failed because of ineffectiveness or side effects, erenumab decreased the number of days with headache from $21.1 \pm 0.7$ days/month to $11.4 \pm 0.9(\mathrm{p}<0.001)$ and $8.9 \pm 0.7$ $(\mathrm{p}<0.001)$ days at months 3 and 6 , respectively. Pain severity, migraine-related disability, impact on daily life, quality of life, allodynia, sleep quality, depression, and anxiety symptoms improved, and MIG-SCOG (subjective cognitive deficit score caused by migraine attacks) did not change. In this study, of which safety results were consistent with those of the randomized controlled studies, $25.7 \%$ of the patients had AEs, and the most common AEs were constipation (23.9\%), fatigue (7\%), and nausea $(5 \%)$. No SAE was observed, and no patient discontinued treatment because of AEs (75).

In a retrospective cohort studyfrom the USA which was based on a database search the use of acute migraine-specific drugs (triptan and ergotamine) was reduced or stopped initiating erenumab treatment. According to the drug records 12 months before (pre-index) and at least 6 months (post-index) after the start of erenumab, migraine-specific acute treatments were discontinued (triptan, $35.9 \%$; ergotamine, $60.5 \%$ ) in $36.8 \%$ of 23,222 patients, who used acute migraine-specific drugs in the pre- and post-index periods treated with at least three doses of erenumab, and doses were reduced $[80.7 \%$ in triptan users (mean reduction, $1.2 \pm 6.6$ units) and $60.7 \%$ in ergotamine users (mean reduction, $0.4 \pm 6.9$ units)] in $80 \%$ of patients (76).

Preliminary results of an observational study conducted in the USA in patients with CM, most of whom had previously used $\geq 5$ preventive treatments, including botulinum toxin, showed that 3 months of erenumab treatment reduced MMD from 16.5 to 7.5 and reduced migraine disability score from 62 to 49 . In $42.5 \%$ of patients using botulinum toxin, it was possible to reduce or discontinue this treatment in the process (77).

In Germany, TELESCOPE and PERISCOPE “online” survey studies revealed the evaluations of physicians and patients with migraine (non-physician) regarding their erenumab treatment experience. In an interim analysis of the PERISCOPE study, 85\% of 91 patients who had previously used an average of six different preventive treatments and had been using erenumab for at least 3 months were able to cope better with their daily work after starting erenumab treatment, $83 \%$ experienced fewer days lost due to migraine, $47 \%$ felt improvement in migraine symptoms beginning from the first injection, and $67 \%$ had decreased severity and duration of attacks (78). In the interim analysis of the TELESCOPE study based on observation of 109 patients, physicians reported that the effect of erenumab was evident in $75 \%$ of their patients from the first dose reducing pain intensity and frequency in $80 \%$ and $92 \%$ of patients, respectively (79).

\section{Conclusions}

Problems with the effectiveness, safety, and tolerability of conventional preventive drugs that were originally developed for diseases other than migraine limit their use for sufficient duration in migraine. Furthermore, most patients are at risk of medication overuse headaches because of the ineffectiveness of attack treatments. Sustainable preventive treatment is important in improving the quality of life of patients with migraine and reducing the socioeconomic burden of the disease.

Erenumab is the first and only preventive therapy in the class of monoclonal antibodies developed against the receptor of CGRP, a neuropeptide that plays a central role in migraine pathophysiology. It is a fully human IgG2 monoclonal antibody designed to bind to the CGRP receptor with high affinity and selectivity. Erenumab administered at subcutaneous doses of $70 \mathrm{mg}$ or $140 \mathrm{mg}$ once a month provides a consistent and sustainable effect that is noticeable from the first week of treatment in patients with EM and CM. Its safety and tolerability profile was comparable with placebo. Findings from current real-life studies are consistent with those from the clinical development program. Real-life studies will continue to guide migraine management in daily practice, reflecting clinical experience in different patient populations.

\section{Aknowledgement}

Dr. İdilhan Baloğlu Ar created tables based on authors' directions, compiled authors' comments, cited references and provided language support.

\section{Ethics}

Peer-review: Externally peer-reviewed.

\section{Authorship Contributions}

Literature Search: A.Ö., D.U., Ö.K., M.M.B., Writing: A.Ö., D.U., Ö.K., M.M.B.

Conflict of Interest: Dr. Manal Mehtar Bozkurt, who is among the authors, is a medical doctor and Clinical Pharmacology Specialist working at Novartis as Erenumab medical manager. In this article, his knowledge about the pharmacological and pharmacodynamic information of the Erenumab molecule was consulted, and his name was therefore included among the authors. We declare this situation as the authors.

Financial Disclosure: No financial support was received from any company, including Novartis, for this study.

\section{References}

1. Headache Classification Committee of the International Headache Society (IHS) the International Classification of Headache Disorders, 3rd edition. Cephalalgia 2018;38:1-211.

2. Raggi A, Giovannetti AM, Quintas R, et al. A systematic review of the psychosocial difficulties relevant to patients with migraine. J Headache Pain 2012;13:595-606.

3. Martelletti P, Schwedt TJ, Lanteri-Minet M, et al. My Migraine Voice survey: a global study of disease burden among individuals with migraine for whom preventive treatments have failed. J Headache Pain 2018;19:115.

4. Leonardi M, Raggi A. A narrative review on the burden of migraine: when the burden is the impact on people's life. J Headache Pain 2019;20:41.

5. Doane MJ, Gupta S, Fang J, Laflamme AK, Vo P. The Humanistic and Economic Burden of Migraine in Europe: A Cross-Sectional Survey in Five Countries. Neurol Ther 2020;9:535-549.

6. Bigal ME, Serrano D, Buse D, et al. Acute migraine medications and evolution from episodic to chronic migraine: a longitudinal populationbased study. Headache 2008;48:1157-1168.

7. Lipton RB, Fanning KM, Buse DC, et al. Migraine progression in subgroups of migraine based on comorbidities: Results of the CaMEO Study. Neurology 2019;93:e2224-e2236.

8. Çimen Atalar A, Yalın OÖ. Investigation of the risk factors for the transition of episodic migraines to chronic migraines. Agri 2019;31:172-177.

9. Institute for Health Metrics and Evaluation website. GBD 2019 results tool http://ghdx.healthdata.org/gbd-results-tool Accessed date: 15.03.2021.

10. Ertas M, Baykan B, Orhan EK, et al. One-year prevalence and the impact of migraine and tension-type headache in Turkey: a nationwide home-based study in adults. J Headache Pain 2012;13:147-157.

11. Baykan B, Ertas M, Karlı N, et al. Migraine incidence in 5 years: a population-based prospective longitudinal study in Turkey. J Headache Pain 2015;16:103. 
12. Steiner TJ, Stovner LJ, Vos T, Jensen R, Katsarava Z. Migraine is first cause of disability in under 50s: will health politicians now take notice?. J Headache Pain 2018;19:17.

13. Lipton RB, Silberstein SD. Episodic and chronic migraine headache: breaking down barriers to optimal treatment and prevention. Headache. 2015;55(Suppl 2):103-126.

14. Bloudek LM, Stokes M, Buse DC, et al. Cost of healthcare for patients with migraine in five European countries: results from the International Burden of Migraine Study (IBMS). J Headache Pain 2012;13:361-378.

15. Manack A, Buse DC, Serrano D, Turkel CC, Lipton RB. Rates, predictors, and consequences of remission from chronic migraine to episodic migraine. Neurology 2011;76:711-718.

16. Fanciullacci M, De Cesaris F. Preventing chronicity of migraine. J Headache Pain 2005;6:331-333.

17. Gürsoy AE, Ertaş M. Prophylactic Treatment of Migraine. Noro Psikiyatr Ars. 2013;50(Suppl 1):30-35.

18. American Headache Society. The American Headache Society Position Statement on Integrating New Migraine Treatments into Clinical Practice. Headache 2019;59:1-18.

19. Öztürk M. Primer Başağrıları Migren- Atak ve Önleyici Tedavi. Şebnem Bıçakcı, Musa Öztürk, Serap Üçler, Necdet Karlı, Aksel Siva Başağrısı Tanı ve Tedavi Güncel Yaklaşımlar 1. Baskı İstanbul, Basım yeri: Üniform Basım San. ve Turizm Ltd. Şti., Yayınevi: Galenos Yayınevi, 2018:51-66.

20. Blumenfeld AM, Bloudek LM, Becker WJ, et al. Patterns of use and reasons for discontinuation of prophylactic medications for episodic migraine and chronic migraine: results from the second international burden of migraine study (IBMS-II). Headache 2013;53:644-655.

21. Hepp Z, Dodick DW, Varon SF, et al. Persistence and switching patterns of oral migraine prophylactic medications among patients with chronic migraine: A retrospective claims analysis. Cephalalgia 2017;37:470-485.

22. Bonafede M, McMorrow D, Noxon V, et al. Care Among Migraine Patients in a Commercially Insured Population. Neurol Ther 2020;9:93-103.

23. Russo AF. Calcitonin gene-related peptide (CGRP): a new target for migraine. Annu Rev Pharmacol Toxicol 2015;55:533-552.

24. Edvinsson L, Haanes KA, Warfvinge K, Krause DN. CGRP as the target of new migraine therapies - successful translation from bench to clinic. Nat Rev Neurol 2018;14:338-350.

25. Edvinsson L. The CGRP Pathway in Migraine as a Viable Target for Therapies. Headache 2018;58(Suppl 1):33-47.

26. Levin M, Silberstein SD, Gilbert R, et al. Basic Considerations for the Use of Monoclonal Antibodies in Migraine. Headache 2018;58:1689-1696.

27. Tepper D. Gepants. Headache 2020;60:1037-1039.

28. Hargreaves R, Olesen J. Calcitonin Gene-Related Peptide Modulators The History and Renaissance of a New Migraine Drug Class. Headache 2019;59:951-970

29. Lassen LH, Haderslev PA, Jacobsen VB, et al. CGRP may play a causative role in migraine. Cephalalgia 2002;22:54-61.

30. Edvinsson L, Warfvinge $\mathrm{K}$. Recognizing the role of CGRP and CGRP receptors in migraine and its treatment. Cephalalgia 2019;39:366-373.

31. Shi L, Lehto SG, Zhu DX, et al. Pharmacologic Characterization of AMGS 334, a Potent and Selective Human Monoclonal Antibody against the Calcitonin Gene-Related Peptide Receptor. J Pharmacol Exp Ther 2016;356:223-231.

32. Sacco S, Bendtsen L, Ashina M, et al. European headache federation guideline on the use of monoclonal antibodies acting on the calcitonin gene related peptide or its receptor for migraine prevention. J Headache Pain 2019;20:6. Erratum in: J Headache Pain 2019;20:58.

33. New Drug Approvals in the USA, Europe and Japan Available from: https:// www.genome.jp/kegg/drug/br08328.html. Access date:15.03.2021.

34. Andreou AP, Fuccaro M, Lambru G. The role of erenumab in the treatment of migraine. Ther Adv Neurol Disord 2020;13:1756286420927119.

35. AIMOVIG (Erenumab-aooe) label. Available from: https://www.accessdata. fda.gov/drugsatfda_docs/label/2018/761077s0001bl.pdf Access date: 10.08.2020

36. AJOVY (Fremanezumab-vfrm) label. Available from: https://www. accessdata.fda.gov/drugsatfda_docs/label/2018/761089s000lbl.pdf Access date: 10.08 .2020 .
37. EMGALTY (Galcanezumab-gnlm) label. Available from: https://www accessdata.fda.gov/drugsatfda_docs/label/2019/761063s003lbl.pdf Access date: 10.08 .2020 .

38. Eptinezumab full prescribing information Available from: https://www. accessdata.fda.gov/drugsatfda_docs/label/2020/761119s000lbl.pdf Access date: 10.08.2020.

39. King CT, Gegg CV, Hu SN, et al. Discovery of the Migraine Prevention Therapeutic Aimovig (Erenumab), the First FDA-Approved Antibody against a G-Protein-Coupled Receptor. ACS Pharmacol Transl Sci 2019;2:485-490.

40. Vidarsson G, Dekkers G, Rispens T. IgG subclasses and allotypes: from structure to effector functions. Front Immunol 2014;5:520.

41. Hui GK, Gardener AD, Begum H, et al. The solution structure of the human IgG2 subclass is distinct from those for human IgG1 and IgG4 providing an explanation for their discrete functions. J Biol Chem 2019;294:1078910806.

42. Sun H, Dodick DW, Silberstein S, et al. Safety and efficacy of AMGS 334 for prevention of episodic migraine: a randomised, double-blind, placebocontrolled, phase 2 trial. Lancet Neurol 2016;15:382-390.

43. Tepper S, Ashina M, Reuter U, et al. Safety and efficacy of erenumab for preventive treatment of chronic migraine: a randomised, double-blind, placebo-controlled phase 2 trial. Lancet Neurol 2017;16:425-434.

44. Goadsby PJ, Reuter U, Hallström Y, et al. A Controlled Trial of Erenumab for Episodic Migraine. N Engl J Med 2017;377:2123-2132.

45. Dodick DW, Ashina M, Brandes JL, et al. ARISE: A Phase 3 randomized trial of erenumab for episodic migraine. Cephalalgia 2018;38:1026-1037.

46. Reuter U, Goadsby PJ, Lanteri-Minet M, et al. Efficacy and tolerability of erenumab in patients with episodic migraine in whom two-to-four previous preventive treatments were unsuccessful: a randomised, double-blind, placebo-controlled, phase 3b study. Lancet 2018;392:2280-2287.

47. Erenumab Kisa ürün bilgisi Available at: https://titck.gov.tr/storage/ Archive/2021/kubKtAttachments/kuzelva70onaylkb_d3c7d61c-35624b9f-8a8b-7317b66cad57.pdf Access date: 30.03.2021.

48. Schwedt T, Reuter U, Tepper S, et al. Early onset of efficacy with erenumab in patients with episodic and chronic migraine. J Headache Pain 2018;19:92.

49. Ashina M, Goadsby PJ, Reuter U, et al. Long-term efficacy and safety of erenumab in migraine prevention: Results from a 5-year, open-label treatment phase of a randomized clinical trial. Eur J Neurol 2021;28:17161725 .

50. Goadsby PJ, Reuter U, Hallström Y, et al. One-year sustained efficacy of erenumab in episodic migraine: Results of the STRIVE study. Neurology 2020;95:e469-e479.

51. Tepper SJ, Ashina M, Reuter U, et al. Long-term safety and efficacy of erenumab in patients with chronic migraine: Results from a 52-week, openlabel extension study. Cephalalgia 2020;40:543-553.

52. Goadsby PJ, Paemeleire K, Broessner G, et al. Efficacy and safety of erenumab (AMGS334) in episodic migraine patients with prior preventive treatment failure: A subgroup analysis of a randomized, double-blind, placebo-controlled study. Cephalalgia 2019;39:817-826.

53. Reuter U, Schwedt TJ, Kudrow D, et al. Long-term Efficacy of Erenumab in Patients With Episodic Migraine Who Have Failed Prior Preventive Migraine Therapies (P1.10-020). Abstracts: AAN 71st Annual Meeting, Philadelphia, USA. Neurology 2019;92(15 Suppl)10-020.

54. Reuter U, Goadsby PJ, Lanteri-Minet M, et al. Sustained efficacy and safety of erenumab in patients with episodic migraine who failed 2-4 prior preventive treatments: 2-year interim results of the LIBERTY open-label extension study. Abstracts: AHS 62nd Annual Scientific Meeting (Virtual). Headache 2020;60(SI suppl):96.

55. Lipton RB, Tepper SJ, Silberstein SD, et al. Reversion from chronic migraine to episodic migraine following treatment with erenumab: Results of a posthoc analysis of a randomized, 12-week, double-blind study and a 52-week, open-label extension. Cephalalgia 2021;41:6-16.

56. Ashina M, Tepper S, Brandes JL, et al. Efficacy and safety of erenumab (AMGS334) in chronic migraine patients with prior preventive treatment failure: A subgroup analysis of a randomized, double-blind, placebocontrolled study. Cephalalgia 2018;38:1611-1621. 
57. Tepper SJ, Diener HC, Ashina M, et al. Erenumab in chronic migraine with medication overuse: Subgroup analysis of a randomized trial. Neurology 2019;92:e2309-e2320.

58. Tepper SJ, Dodick DW, Lucas S, et al. Efficacy of Erenumab in Chronic Migraine (CM) Patients With Acute Headache Medication Overuse (MO): A Post Hoc Analysis Assessing Outcomes Using Different Definitions of Remission. AHS 62nd Annual Scientific Meeting (Virtual). Headache 2020;60(S1 suppl):105.

59. Tepper S, Lipton R, Silberstein S, et al. Long-term efficacy of erenumab in chronic migraine $(\mathrm{CM})$ patients with or without acute medication overuse (AMO). Neurology 2020;94(15 Suppl):006.

60. Lipton RB, Buse DC, Dodick DW, et al. Efficacy of Erenumab in Chronic Migraine Patients with and Without Allodynia. Abstracts: AHS 61st Annual Scientific Meeting Philadelphia, USA. Headache 2019;59(SI suppl): 101 .

61. Buse DC, Lipton RB, Hallström Y, et al. Migraine-related disability, impact, and health-related quality of life among patients with episodic migraine receiving preventive treatment with erenumab. Cephalalgia 2018;38:16221631.

62. Lipton RB, Tepper SJ, Reuter U, et al. Erenumab in chronic migraine: Patient-reported outcomes in a randomized double-blind study. Neurology 2019;92:e2250-e2260.

63. Pascual J, Buse DC, Starling A, et al. Effect of erenumab on patient-reported outcomes in episodic migraine patients with prior prophylactic treatment failure: Results from a post-hoc analysis of the STRIVE study (065). MTIS 2018 Abstracts. Cephalalgia 2018;38(1_suppl):1-115.

64. Lanteri-Minet M, Buse CD, Staarling A, et al. Patient-Reported Outcomes in chronic migraine patients with prior prophylactic treatment failure receiving placebo or erenumab: subgroup analysis of a pivotal randomised study (066). MTIS 2018 Abstracts. Cephalalgia 2018;38(1_suppl):1-115.

65. Lattanzi S, Brigo F, Trinka E, et al. Erenumab for Preventive Treatment of Migraine: A Systematic Review and Meta-Analysis of Efficacy and Safety. Drugs 2019;79:417-431.

66. Zhu C, Guan J, Xiao H, Luo W, Tong R. Erenumab safety and efficacy in migraine: A systematic review and meta-analysis of randomized clinical trials. Medicine (Baltimore) 2019;98:e18483.

67. Lampl C, Snellman J, Ritter S, Klatt J. Safety and tolerability of erenumab in older migraine patients: A subgroup analysis of randomised trials (1207). Neurology 2020;94 (15 Suppl):1207.

68. Kudrow D, Pascual J, Winner PK, et al. Vascular safety of erenumab for migraine prevention. Neurology 2020;94:e497-e510. Erratum in: Neurology 2020;94:1052.

69. Drug Safety-related Labeling Changes. Available from: https:// www.accessdata.fda.gov/scripts/cder/safetylabelingchanges/index. cfm? event $=$ searchdetail.page $\&$ DrugNameID $=1894 \#$ Access date 15.08.2020.

70. Franklin SS, Khan SA, Wong ND, Larson MG, Levy D. Is pulse pressure useful in predicting risk for coronary heart disease? The Framingham heart study. Circulation 1999;100:354-360.

71. Franklin SS, Larson MG, Khan SA, et al. Does the relation of blood pressure to coronary heart disease risk change with aging? The Framingham heart study. Circulation 2001;103:1245-1249.

72. Ashina M, Kudrow D, Reuter U, et al. Long-term tolerability and nonvascular safety of erenumab, a novel calcitonin gene-related peptide receptor antagonist for prevention of migraine: A pooled analysis of four placebo-controlled trials with long-term extensions. Cephalalgia 2019;39:1798-1808.

73. Vargas B, Starling A, Silberstein S, et al. Erenumab Immunogenicity: a Pooled Analysis of Phase 2 and Phase 3 Migraine Prevention Clinical Trials (P4.098). Abstracts: AAN 70th Annual Meeting, Los Angeles Neurology Apr 2018, 90(15 Suppl):098.

74. Barbanti P, Aurilia C, Cevoli S, et al. The First, Italian, Multicenter, Reallife Study with Erenumab in the Prevention of High Frequency Episodic and Chronic Migraine. Neurology 2020;94(15 Suppl):2307.

75. Russo A, Silvestro M, Scotto di Clemente F, et al. Multidimensional assessment of the effects of erenumab in chronic migraine patients with previous unsuccessful preventive treatments: a comprehensive real-world experience. J Headache Pain 2020;21:69.

76. Hines D, Shah S, Multani J, et al. Changes in Acute Migraine-Specific Medications after Initiating Erenumab: Results from a Real-World Retrospective Cohort Study in the United States (EPR 3047). Abstracts of the 6th Congress of the European Academy of Neurology (virtual congress). Eur J of Neurol 2020;27(Suppl 1):103-502.

77. Zyloney C, Barker C, Yu Y, Villanueva R, Schwarz H. Post marketing experiences with erenumab (Aimovig) for the treatment of chronic migraine in a real life clinical setting. Neurology 2020; 94(15 Suppl):254.

78. Gaul C, Israel-Willner H, Schuh K, Koch M. First-Hand Impressions of the monoclonal Antibody in Migraine Prevention from Patients treated with Erenumab in Germany. Neurology 2020;94(15 Suppl):3997.

79. Straube A, Stude P, Gaul C, Koch M, Schuh K. First one-year real world evidence data with the monoclonal antibody erenumab in Germany. Neurology 2020;94(15 Suppl):1873. 